\title{
Scour control at bridge piers using macro-roughness elements
}

4

5

6

8

9

10

11
Stefano Pagliara, IAHR Member

Professor, DESTEC-Department of Energy Engineering, Systems, Land and Construction

University of Pisa, Via Gabba 22, 56122, Pisa, Italy.

Phone: +39 050 2217717; Fax: +39050 2217730; E-mail: s.pagliara@ing.unipi.it

(Corresponding Author)

\section{Michele Palermo}

Ph.D., IAHR Member, DESTEC-Department of Energy Engineering, Systems, Land and Construction, University of Pisa, Via Gabba 22, 56122, Pisa, Italy.

E-mail: michele.palermo@,ing.unipi.it

\section{Reza Azizi}

Ph.D., Faculty of Water Science Engineering

Shahid Chamran University, Golestan Blvd., Ahvaz, Iran. E-mail: re azizi@ymail.com

\section{Number of figures and tables: 15}

Number of words: 5000 


\section{Abstract}

2 A new approach involving macro-roughness elements is proposed as scour countermeasure at circular

3 bridge piers in presence of debris accumulation. Experiments are carried out under clear-water

4 conditions with the approaching flow velocity set at the threshold of the sediment motion. The

5 efficiency of the method is investigated in terms of scour morphology reduction and temporal scour

6 evolution. Results show the effectiveness of the method in reducing maximum scour depth. In some

7 cases, elements do not reduce the maximum scour depth; but they are efficient in reducing volume of

8 the scour hole. Based on the experimental data, empirical equations are derived to estimate the

9 temporal local scour depth both in presence of debris accumulation and macro-roughness elements.

\section{Notation}

$12 A_{t b}=$ total flow blockage area by debris accumulation and bridge pier $\left[\mathrm{m}^{2}\right]$

$A_{m}=\pi D_{m}^{2} / 4=$ projected area of macro-roughness element $\left[\mathrm{m}^{2}\right]$

$A_{s}=$ planar area of scour hole $\left[\mathrm{m}^{2}\right]$

$b=$ channel width $[\mathrm{m}]$

$d_{16,} d_{50}, d_{84}=$ size of bed material diameter for which $16 \%, 50 \%$, and $84 \%$ is finer, respectively [m]

$d_{d}=$ debris width $[\mathrm{m}]$

$d_{s}=$ scour depth $[\mathrm{m}]$

$D=$ pier diameter $[\mathrm{m}]$

$D_{m}=$ Average diameter of macro-roughness element $[\mathrm{m}]$

$21 f=$ function symbol [-]

$\boldsymbol{F}_{d}=U /\left(g^{\prime} d_{50}\right)^{1 / 2}=$ densimetric Froude number [-]

$g=$ acceleration due to gravity $\left[\mathrm{m} / \mathrm{s}^{2}\right]$

$g^{\prime}=g \Delta=$ reduced gravitational acceleration $\left[\mathrm{m} / \mathrm{s}^{2}\right]$

$h=$ approaching flow depth [m]

$h_{d}=$ debris heigth $[\mathrm{m}]$ 
$1 \quad l_{d}=$ debris length $[\mathrm{m}]$

$2 L=$ Distance between the first and the last row of macro-roughness elements [m]

$3 n$ = Manning's coefficient $\left[\mathrm{s} / \mathrm{m}^{1 / 3}\right]$

$4 \quad N=$ total number of macro-rough elements [-]

$5 \quad \mathrm{R}_{p}=U D / v=$ pier Reynolds number [-]

$6 \quad S_{o}=$ bed slope [-]

$7 \quad t=$ time [minute]

$8 \quad t_{d}=$ Debris submergence $[\mathrm{m}]$

$9 \quad T^{*}=$ non-dimensional time [-]

$10 U=$ approaching flow velocity $[\mathrm{m} / \mathrm{s}]$

$11 U_{c}=$ critical flow velocity $[\mathrm{m} / \mathrm{s}]$

$12 V_{s}=$ scour hole volume $\left[\mathrm{m}^{3}\right]$

$13 x=$ longitudinal coordinate $[\mathrm{m}]$

$14 y=$ transversal coordinate $[\mathrm{m}]$

$15 z=$ vertical coordinate $[\mathrm{m}]$

$16 \quad z_{r}=$ ridge height $[\mathrm{m}]$

$17 \Gamma=N A m / b L=$ non-dimensional concentration of macro-roughness elements [-]

$18 \Delta=\left(\rho_{s}-\rho\right) / \rho=$ relative density of submerged sediment [-]

$19 \Delta A=\left[\left(d_{d}-D\right) t_{d}\right] /(b h) \times 100=$ blockage ratio percentage $[\%]$

$20 \delta_{n}$ and $\delta_{s}=$ transversal and longitudinal distances of macro-roughness elements [m]

$21 v=$ kinematic viscosity $\left[\mathrm{m}^{2} / \mathrm{s}\right]$

$22 \rho=$ water density $\left[\mathrm{kg} / \mathrm{m}^{3}\right]$

$23 \rho_{s}=$ sediment density $\left[\mathrm{kg} / \mathrm{m}^{3}\right]$

$24 \sigma=$ sediment uniformity coefficient [-]

$25 \phi$ and $\phi^{\prime}=$ dry and wet sediment angle of repose [deg] 


\section{Subscripts}

$2 c=$ critical condition

$3 \quad d=$ debris

$4 \quad m=$ macro-roughness element

$5 \quad s=$ scour hole

$6 \max =$ maximum value

7

8 Keywords: Bridges, Piles \& piling, River Engineering.

9

10 


\section{Introduction}

Scour phenomenon at bridge piers is one of the most important causes of structural failure. In these conditions, accumulations of floating debris in correspondence with piers increase the obstruction to the flow. Larger obstructions accelerate the two-phase water-sediment flow velocity around the pier, resulting in an increase of the scour depth, planar surface area and volume of the scour hole.

Several approaches and design criteria have been suggested to reduce the scour at bridge piers, including different countermeasure systems, e.g., collars (Thomas 1967, Tanaka and Yano 1967, Ettema 1980), bed-sills (Grimaldi et al. 2009a, Pagliara et al. 2010), Iowa vanes (Odgaard and Wang 1967, Ghorbani and Kells 2008), collar-riprap (Chiew 1995, Zarrati et al. 2006), slot-collar (Kumar et al. 1999, Moncada-M et al. 2009). In addition, several studies are present in literature dealing with bridge pier scour in the presence of debris accumulation (Melville and Dongol 1992, Diehl 1997, Lagasse et al. 2009, Pagliara and Carnacina 2010, Pagliara and Carnacina 2011). However, according to authors' knowledge, no systematic studies regarding scour protection efficiency of the countermeasures in the presence of debris accumulation have been carried out. Thus, the present research aims to investigate the scour process in the presence of both "macro-roughness elements" and debris accumulation.

Countermeasures are effective if they reduce scour depth and limit scour surface and volume (Yanmaz and Köse 2006, Pagliara and Palermo 2008a-b, Pagliara and Palermo 2010, Pagliara and Palermo 2011). The present study aims to test a simple, effective and affordable countermeasure to reduce the main geometric features of scour hole at bridge piers in the presence of the debris accumulation.

\section{Material and methods}

Experiments were conducted in a channel $7.6 \mathrm{~m}$ long, $0.61 \mathrm{~m}$ wide and $0.5 \mathrm{~m}$ deep at the University of Pisa, Pisa, Italy. A single plexiglass cylinder of diameter $D=0.03 \mathrm{~m}$ was fixed axially to the channel bottom to simulate bridge pier. Figure 1 shows a diagram sketch of the experimental channel. 
1 For small pier diameter $(D / b<0.1)$, where $b=$ channel width, pier contraction slightly affects the scour process (Laursen and Toch 1956, Hager and Oliveto 2002). For the present tests $D / b=0.05$. Effects of the pier Reynolds number $\left(\mathrm{R}_{p}\right)$ can be considered negligible as $\mathrm{R}_{p}=U D / v>7000$ (Franzetti et al. 1994), where $U=$ approaching flow velocity measured at $10 D$ upstream of the pier and $v=$ kinematic viscosity of fluid. A tail-gate at the end of the channel was used to regulate the flow depth $(h)$. A schematic diagram including hydraulic and geometric parameters is shown in Fig. 2.

Tests were performed using sand with $d_{50}=1.0 \mathrm{~mm}, \sigma=\left(d_{84} / d_{16}\right)^{1 / 2}=1.2$, dry and wet angle of repose $\phi=31^{\circ}$ and $\phi^{\prime}=36^{\circ}$, respectively, and $\Delta=\left(\rho_{s}-\rho\right) / \rho=1.44$, where $\rho_{s}=$ sediment density and $\rho=$ water density. Table 1 reports the granulometric characteristics of the tested channel bed material. According to Raudkivi and Ettema (1983), Melville and Chiew (1999), and Oliveto and Hager (2005), for a sediment size with $d_{50}>0.9 \mathrm{~mm}$, bed forms do not occur and the cohesive effects can be neglected. The sediment entrainment velocity was estimated adopting the criterion proposed by $\mathrm{Wu}$ and Wang (1999) and the energy line slope was calculated by Manning's formula, in which the resistance coefficient is $n=d_{50}{ }^{1 / 6} / A$, with $A=21.1$ (Strickler, 1923).

Debris accumulation was simulated using different plexiglass boxes (Fig. 3). Namely, two debris lengths $l_{d}$ were tested $\left(l_{d}=5 D\right.$ and $\left.3 D\right)$, termed as debris $5 D$ and $3 D$, respectively. The geometric dimensions of debris 5D were $l_{d}=0.15 \mathrm{~m}, d_{d}=0.20 \mathrm{~m}$ and $h_{d}=0.09 \mathrm{~m}$, whereas $l_{d}=0.09 \mathrm{~m}, d_{d}=$ $0.17 \mathrm{~m}$ and $h_{d}=0.16 \mathrm{~m}$ for debris $3 D . d_{d}$ and $h_{d}$ are debris width and height, respectively. Debris were movable in order to obtain different values of the submergence $\left(t_{d}\right)$, as shown in Figures $2 \mathrm{~b}$-c.

To simulate macro-roughness elements, two different uniform gravel materials where adopted, whose mean diameter $D_{m}=0.015$ and $0.025 \mathrm{~m}$, respectively. For all tests, a total number of $N=25$ elements were arranged according to the scheme illustrated in Figs. 2a and 4: rock elements were located in rows spaced $\delta_{s}=0.155 \mathrm{~m}$ longitudinally and $\delta_{n}=0.14 \mathrm{~m}$ transversely, respectively. The first transversal row was located at a distance equal to $D$ from the pier. A dimensionless concentration parameter $\Gamma=N A m / b L=\pi N D_{m}^{2} / 4 b L$ is defined to assess the effect of macro-roughness elements on 
1 scour phenomenon. $b=$ channel width and $L=$ longitudinal distance between first and last rows of the macro-roughness elements (Fig. 2a). Note that $L \cong b$.

A total of 57 tests were carried out. For each test, maximum scour depth $\left(d_{s}\right)$ were measured at different instants from the test beginning, i.e., $t=1,2,4,8,15,30,60$ up to 360 minutes. In addition, some longer tests were conducted up to 4320 minutes. In order to analyze the effect of the percentage blockage ratio of debris on the phenomenon, several submergence ratios $\Delta A=\left[\left(d_{d}-D\right) t_{d} / b h\right] \times 100$ were tested (Pagliara et al. 2010), in which $t_{d}=$ submerged thickness of debris. Before each test beginning, channel bed was carefully leveled. Water flow was allowed to enter the channel very slowly to avoid scour around the pier during the set-up of test conditions. According to Pagliara and Carnacina (2010), maximum scour depth was measured by using a $\pm 0.5 \mathrm{~mm}$ precise clear scale glued directly on the pier. Scour hole pattern and final bed topography was surveyed by using a $\pm 0.1 \mathrm{~mm}$ precise point gauge.

\section{Results and discussion}

\subsection{Morphological analysis}

The morphological characteristics of the downstream ridge have a deep influence of the erosive process. The ridge migration allows for a scour hole evolution. Thus, the analysis of its morphology and its variation due to the different macro-roughness elements arrangements is of fundamental importance. In Figure 5a-d, the evolution of the ridge morphology is shown for two different submergence ratio of debris accumulations $(\Delta A=6 \%$ and $18 \%)$ and for $h / D=5.67, l_{d} / D=3, D_{m} / D=$ 0.83. Namely, Figs. 5a and 5c shows the developing morphology (60 and 30 minutes from the test beginning, respectively) and Fig. $5 \mathrm{~b}$ and $5 \mathrm{~d}$ show the developed morphology (after 360 and 60 minutes, respectively) for $\Delta A=6 \%$ and $18 \%$, respectively. For $\Delta A=18 \%$, a scour region occurs also downstream of the ridge. This is mainly due to the ridge dimension and the relative quite steep slope 
1 morphology is more similar to that occurring for $\Delta A=6 \%$. It means the effect of the obstruction is very prominent for $\Delta A=18 \%$ and it deeply influences the global scour dynamic.

3 The evolution of the downstream border contour of the ridge is shown in Fig. 6 for both $\Delta A=6 \%$ and

$4 \quad 18 \%$ and for $h / D=5.67, l_{d} / D=3, D_{m} / D=0.5 . y / D$ and $x / D$ are the non-dimensional transverse and

5 longitudinal coordinates, respectively. The origin of the reference system is at pier center. Figures 7 and 8 show the variation of the non-dimensional maximum ridge height $z_{r, \max } / D$ (occurring axially in the channel) versus the non-dimensional time $T^{*}$ (see below for this parameter definition), for tests reported in figure legends. In general, two different behaviors can be detected. According to Fig. 7, for $h / D=1.40$ and 2.67, the maximum ridge height occurs in the first minutes after the test beginning, whereas, according to Fig. 8 , for $h / D=5.67$ the maximum ridge height occurs at $t \approx 30$ min. Then, for all the tested conditions, the ridge tended to be flattened. This difference is mostly due

to the fact that, for high tailwater, the ridge migration is less fast than for otherwise tailwater conditions. Thus, eroded sediment accumulate forming a more prominent ridge. Table 2 reports experimental tests characteristics and conditions.

Contours of some selected tests are reported in Fig. 9 to show the effect of macro-roughness elements on scour planar area. In fact, even if in some cases the effect of these elements on scour depth is not prominent, generally, they contribute to confine the planar extension of the scour hole. In the proposed figure, pier and macro-roughness elements are schematically represented. In particular, Figure 9 compares the morphology of the channel bed at the end of the tests for two different tailwater and discharge conditions, in the presence of debris $5 \mathrm{D}$ and for $\Delta A=6 \%$. Namely, the base morphological configurations (Fig. 9a and d) are compared with the respective ones in the presence of both tested macro-roughness elements. It is evident that, for both low (Fig. 9a-c) and medium (Fig. 9d-f) tailwater conditions, the presence of macro-roughness elements in the scoured surface is relatively significant. In addition, also their effect on ridge migration can be easily detected: ridge migration is reduced and the transversal expansion is limited. The effect is more prominent for bigger macro-roughness 
1 elements. Nevertheless, the confinement of the scour hole can lead to a slight increase of the scour depth in some peculiar cases (see for example Figure 9d and f).

\subsection{Dynamic of the scour hole evolution}

The presence of macro-roughness elements increases the stability of the base material, as they cause form drag forces which increase the total flow resistance and diminish the shear stress acting on the base material (Morris 1959, Ferro 1999, Lawrence 2000). In particular, the scour morphology variation due to the presence of macro-roughness elements downstream of the bridge pier is a complex phenomenon depending on a combination of several effects. Namely, the reduction of shear stress acting on the base material is significant and of fundamental importance to understand the physics of the phenomenon as, generally, it determines both a delay and a reduction of the scour process evolution. Furthermore, the shear stress reduction contributes to slow ridge migration, resulting in a confinement of the scoured surface. Finally, there is a further effect due to the macroroughness elements presence on the scour mechanism. Namely, during the scour process evolution, one or several macro-roughness elements roll into the scour hole modifying local flow conditions and, at the same time, contributing to protect base material from further erosion. This last effect is also occurring in the presence of riprap at circular bridge piers and it was described by Unger and Hager (2006). The effect of the macro-roughness elements on the flow depth is practically negligible, as their concentration is quite small $(\Gamma<0.032)$. According to Wang et al (2011), the velocity profiles can be modified by macro-roughness elements depending on the relative roughness, but the variations are restricted to a certain region. At a sufficient distance from the roughness elements, their effect on flow characteristics become negligible. This observation suggests that macro-roughness elements contribute to locally modify the flow structure, as their concentration is very low and $h / D_{m}>1.7$.

Nevertheless, for $D_{m} / D=0.5$, generally, the ridge completely covers some elements, resulting in a reduction of its longitudinal extension. Thus, macro-roughness elements slow ridge migration causing a delay in scour process evolution, especially for low $h / D$, as schematically shown in Fig. 10a. For 
$1 D_{m} / D=0.83$, generally, downstream ridge forms around the macro-roughness elements, resulting in

2 a faster scour rate (Fig. 10b).

3 In all tests, at least one element falls into the scour hole, generally reducing the erosive action of the

4 downflow and horseshoe vortex. For higher flow conditions $(h / D=5.67$ and 2.67) and larger blockage

5 ratio $(\Delta A=18 \%)$, more than one element fall into the scour hole resulting in a better protection of the 6 scour hole itself.

\subsubsection{Scour volume and planar surface characteristics}

9 The effects of macro-roughness elements both in presence and absence of debris is of fundamental importance for design purposes. The analysis has to involve all the scour features including the scoured volume $V_{s}$ and the planar area of the scoured surface $A_{s}$. In fact, for practical applications, also the quantity of transported sediment from the scour hole and its planar extension are important parameters. The comparison between the different configurations tested was conducted both in terms of scour volumes and in terms of scour hole surface. Namely, for each tested condition and for each configuration, the non-dimensional scour volume $\left(V_{S} / D^{3}\right)$ and the non-dimensional scour surface that smaller elements are practically covered by the ridge, contributing to stabilize it, thus resulting in a confinement of the scour hole. This effect becomes less prominent for low tailwater conditions, as the ridge is more easily flattened, thus its confining action reduces. In presence of debris accumulation, the scour volume reduction is more prominent for low blockage ratio $(\Delta A=6 \%)$. In this configuration sensible volume reduction occurs especially for $D_{m} / D=0.5$ (Fig. $11 \mathrm{~b}$ ). The effects of 
macro-roughness elements tend to vanish increasing $\Delta A$, such as the effect of $\Gamma$ (Fig. 11c-d). This is due to the fact that higher $\Delta A$ implies larger scour hole and ridge, thus the confinement effect of macro-roughness elements is negligible (Fig. 11d). Similar comments can be valid also for nondimensional scour hole surface. In fact, the effect of the selected parameters on $A_{s} / D^{2}$ is essentially the same in the presence of debris accumulation (Fig. 11e-h). Whereas, for the base configuration (absence of debris), the maximum scour surface reduction occurs for low tailwater conditions, because of the lateral confinement due to macro-roughness elements.

\subsubsection{Scour depth evolution}

The maximum scour depth at bridge pier in presence of debris accumulation and macro-roughness elements is a key parameter that is extremely important for design purposes. In addition, the temporal evolution of this variable is of fundamental importance in order to understand the dynamic of the erosive processes and the differences due to both the geometric and hydraulic configurations. According to Pagliara and Carnacina (2010 and 2011), the flow intensity and blockage ratio significantly affect the scour depth. Whereas, Oliveto and Hager (2005) showed that, under steady approach flow, the maximum scour depth depends essentially on the densimetric particle Froude number $\boldsymbol{F}_{d}=U /\left(g^{\prime} d_{50}\right)^{1 / 2}$, where $g^{\prime}=g \Delta$. Based on previous studies and considering the new variables introduced in the present work, the functional relationship governing the scour phenomenon can be expressed as follows:

$$
\frac{d_{s}}{D}=\boldsymbol{f}\left(\Delta A, \boldsymbol{F}_{d}, \frac{h}{D}, \frac{l_{d}}{D}, \frac{d_{d}}{D} \Gamma, T^{*}\right)
$$

2 Note that in the present study, $d_{50}$ was constant and $U / U_{c} \approx 1$. In Eq. (1), $\Delta A=\left[\left(d_{d-}-D\right) \cdot t_{d}\right] /(b \cdot h)=$ blockage ratio due to rectangular impervious debris accumulation, $\Gamma=\pi N D_{m}^{2} / 4 b L=$ non-dimensional concentration of macro-roughness elements and $T^{*}=U h t / A_{t b}=$ non-dimensional time parameter in 
1 presence of debris accumulation, in which $t=$ time and $A_{t b}=D \cdot h+\left(d_{d}-D\right) \cdot t_{d}=$ total flow area blocked by bridge pier and debris accumulation (Pagliara and Carnacina 2011).

3 The influence of the independent non-dimensional parameters on the non-dimensional scour depth $d_{s} / D$ has been investigated. Figure 12 shows the temporal scour depth evolution, for $0 \leq \Delta A \leq 18 \%$ in the tested macro-roughness elements configurations (i.e., $\delta_{s}=15.5 \mathrm{~cm}$ and $\delta_{n}=14 \mathrm{~cm}$ and $\Gamma$ varying between 0.012 and 0.032). In particular, the effect of the size of the macro-roughness elements $\left(D_{m} / D\right)$ and its protective efficiency is put in evidence in Fig. 12. Generally, in terms of non-dimensional scour depth, the differences due to the tested elements sizes and concentration are not very prominent. However, in some cases, especially for low blockage ratios, small elements show a higher protection effect (e.g. Fig. 12e and f). Whereas, for high blockage ratio, bigger elements have a better performance in terms of scour reduction efficiency (e.g. Fig. 12j and 1). Nevertheless, there are also some cases, as shown in Fig. 11 and 12, in which macro-roughness elements do not reduce the scour hole features.

The presence of debris accumulations significantly increases the scour depth, as also confirmed by previous studies (Melville and Dongol 1992, Pagliara and Carnacina 2010 and 2011). But, in the present study, it was observed that the width of two debris accumulations has negligible effects on the dependent parameter $d_{s} / D$. This is due to the fact that the ratio $d_{d} / D$ is almost the same for the tested debris (i.e., 5.67 and 6.67 for debris 3D and 5D, respectively). However, temporal evolution data generally show three different behaviors during the erosive process. Namely, three different phases can be distinguished: Phase I, II, and III. Different phases are distinguished by using nondimensional time at the end of each phase $T_{p}{ }^{*}$ (subscript $p=1$ and 2). Phase I occurs for $T^{*}<T_{1}{ }^{*}$. Phase I lasts from the beginning of scour process up to when the first macro-roughness element rolls into the scour hole. In general, in the tested range of parameters, it was observed that $T_{1}{ }^{*}=2.0 \times 10^{3}$. Phase II represents the developing period in which sediment are removed from the scour hole and form the downstream ridge. Phase II occurs for $T_{1}{ }^{*}<T^{*}<T_{2}{ }^{*}$. Experimental data show that $T_{2}{ }^{*}=$ 
$11.0 \times 10^{4}$. In the second phase, macro-roughness elements confine ridge migration, thus delaying scour

2 hole enlargement. Phase III starts when the ridge migrates downstream $\left(T^{*}>T_{2}{ }^{*}\right)$. There are some

3 differences in the ridge migration dynamic and they are mostly due to the different size of elements

4 which affects the migration process. In addition, in the third phase more elements roll into the scour

5 hole contributing to protect it from further erosion, thus resulting in a reduced maximum scour depth.

6 Following the approach proposed by Pagliara et al. (2010), the scour depth evolution occurring in the

7 second and third phase was analyzed and empirical equations are proposed as follows:

$8 \quad \frac{d_{s}}{D}=0.004\left[e^{(2 \Delta A-\Gamma)}\left(\frac{l_{d}}{D}+1\right)^{\Delta A} \mathrm{~F}_{d}^{3.155}\left(\frac{h}{D}\right)^{0.362}\right] \cdot \ln \left(\frac{T^{*}}{10}\right) \quad$ for $2.0 \times 10^{3}<T^{*}<1.0 \times 10^{4}$

$9 \quad \frac{d_{s}}{D}=0.003\left[e^{(2 \Delta A-\Gamma)}\left(\frac{l_{d}}{D}+1\right)^{\Delta A} \mathrm{~F}_{d}^{3.652}\left(\frac{h}{D}\right)^{0.314}\right] \cdot \ln \left(\frac{T^{*}}{10}\right) \quad$ for $T^{*}>1.0 \times 10^{4}$

Equations (2) and (3) predict the scour depths at different instants in phases II and III, respectively. The proposed equations are valid in the following range of parameters: $0 \leq \Delta A \leq 0.18,0 \leq \Gamma \leq 0.032$, $0 \leq l_{d} / D \leq 5$, and $1.4 \leq h / D \leq 5.67$. Comparison between observed and predicted values of scour depths is presented in Fig. 13a-b, for phase II and III, respectively. As shown in Fig. 13, the agreement between experimental and predicted data is good.

For practical and design purposes, the use of macro-roughness elements is a simple and economic approach to control the scour process also in the presence of debris accumulations. Experimental results from Pagliara and Carnacina (2010) proved that efficiency of the scour countermeasures (i.e., sills and gabions) is not prominent in the absence of debris accumulations. In addition, they also showed that in presence of debris, a sill initially delays the scour depth evolution. The present study showed a good performance of the macro-roughness elements as countermeasure technique in the absence of debris accumulations (tests 33, 34, and 37). Furthermore, the present investigation proves a good efficiency of the macro-roughness elements in terms of reduction of maximum scour depth, scour hole volume and surface in presence of large debris accumulations in most of tested conditions. 


\section{Conclusions}

The efficiency of macro-roughness elements is evaluated as a new scour countermeasure at bridge piers in presence of debris accumulation. Macro-roughness elements located downstream of the pier have a significant effect in reducing maximum scour depth in presence of large debris accumulations. In few cases, macro-roughness elements do not reduce the maximum scour depth, but have a significant effect in reducing the volume and planar area of the scour hole. From a practical and economic point of view, this method is comparable with previously suggested methods such as sills and gabions.

Further investigations are required to deepen the effect of different macro-roughness elements configurations on the bed morphology downstream of the pier.

\section{Acknowledgments}

The three authors equally contributed to the paper.

\section{Refrences}

Chiew YM (1995) Mechanics of riprap failure at bridge piers. Journal of Hydraulic Engineering 121(9): 635-643.

Diehl TH (1997) Potential drift accumulation at bridges. Publication FHWA-RD-97-028. Federal Highway Administration, Washington DC.

Ettema R, Melville BW and Barkdoll B (1998) Scale effect in pier-scour experiments. Journal of Hydraulic Engineering 124(6): 639-642.

Ferro V (1999) Evaluating friction factor for gravel bed channel with high boulder concentration. Journal of Hydraulic Engineering 125(7): 771-778.

Franzetti S, Malavasi S and Piccinin C (1994) Sull'erosione alla base delle pile dei ponti in acque chiare. In Atti del 14th Convegno d'Idraulica e Costruzioni Idrauliche, Naples, Italy, pp. 13-24, [in Italian]. 
1 Ghorbani B and Kells JA (2008) Effect of submerged vanes on the scour occurring at a cylindrical pier. Journal of Hydraulic Research 46(5): 610-619.

Grimaldi C, Gaudio R, Calomino F (2009a) Control of scour at bridge piers by a downstream bed sill. Journal of Hydraulic Engineering 135(1): 13-21.

Grimaldi C, Gaudio R, Calomino F (2009b) Countermeasures against local scouring at bridge piers: Slot and combined system of slot and bed sill. Journal of Hydraulic Engineering 135(5): 425431.

Hager WH and Oliveto G (2002) Shields' entrainment criterion in bridge hydraulics. Journal of Hydraulic Engineering 128(5): 538-542.

Kumar V, Ranga Raju KG and Vittal N (1999) Reduction of local scour around bridge piers using slots and collars. Journal of Hydraulic Engineering 125(12): 1302-1305.

Lagasse PF, Clopper PE and Zevenbergen LW (2009) Impacts of debris on bridge pier scour. In Proceedings of 33rd IAHR congress, Vancouver, pp. 3967-3974.

Laursen EM and Toch A (1956) Scour around bridge piers and abutments. Bulletin 4. Iowa Highway research board. Ames, IA.

Lawrence DSL (2000) Hydraulic resistance in overland flow during partial and marginal surface inundation: Experimental observations and modeling. Water Resources Research 36(8): 23812393.

Melville BW and Chiew YM (1999) Time scale of local scour at bridge piers. Journal of Hydraulic Engineering 125(1): 59-65.

Melville BW and Dongol DM (1992) Bridge pier scour with debris accumulation. Journal of Hydraulic Engineering 118(9): 1306-1310.

Morris HM (1959) Design method for flow in rough conduits. Journal of Hydraulic Division-ASCE 85(7): 43-62.

Moncada-M AT, Aguirre-Pe J, Bolivar JC et al. (2009) Scour protection of circular bridge piers with collars and slots. Journal of Hydraulic Research 47(1): 119-126. 
1 Odgaard AJ and Wang Y (1987) Scour prevention at bridge piers. Hydr. Engrg. 87, R.M. Ragan, ed.,

National conference, Virginia, pp. 523-527.

Oliveto G and Hager WH (2005) Further results to time-dependent local scour at bridge elements. Journal of Hydraulic Engineering 131(2): 97-105.

Pagliara S and Palermo M (2008a) Scour control and surface sediment distribution downstream of block ramps. Journal of Hydraulic Research 46(3): 334-343.

Pagliara S and Palermo M (2008b) Scour control downstream of block ramps. Journal of Hydraulic Engineering 134(9): 1376-1382.

Pagliara S and Palermo M (2010) Influence of tailwater depth and pile position on scour downstream of block ramps. Journal of Irrigation and Drainage Engineering 136(2): 120-130.

Pagliara S and Carnacina I (2010) Temporal scour evolution at bridge piers: Effect of wood debris roughness and porosity. Journal of Hydraulic Research 48(1): 3-13.

Pagliara S, Carnacina I and Cigni F (2010) Sills and gabions as countermeasures at bridge pier in presence of debris accumulation. Journal of Hydraulic Research 48(6): 764-774.

Pagliara S and Carnacina I (2011) Influence of wood debris accumulation on bridge pier scour. Journal of Hydraulic Engineering 137(2): 254-261.

Pagliara S and Palermo M (2011) Effect of stilling basin geometry on clear water scour morphology downstream of a block ramp. Journal of Irrigation and Drainage Engineering 137(9): 593-601.

Raudkivi AJ and Ettema R (1985) Scour at cylindrical piers in armored beds. Journal of Hydraulic Engineering 111(4): 713-731.

Strickler A (1923) Beitrage zur Frage der Geschwindigkeitsformel und der Rauhigkeitszahlen fur Strome, Kanale und geschlossene Leitungen. Mitteilungen des Eidgenossischen Amtes fur Wasserwirtschaft 16, Bern, Switzerland (translated as: Contributions to the equation of a velocity formula and roughness data for streams, channels and closed pipelines. By T. Roesgan and W. R. Brownie, Translation T-10, W. M. Keck Lab of Hydraulics and Water Resources, Calif. Inst. Tech., Pasadena, Calif. January 1981). 
1 Tanaka S and Yano M (1967) Local scour around a circular cylinder. In Proceedings of 12th Congress of IAHR, Deft, The Netherlands.

3 Thomas Z (1967) An interesting hydraulic effect occurring at pier scour. In Proceedings of 12th $4 \quad$ Congress of IAHR, Deft, The Netherlands.

5 Unger J and Hager WH (2006) Riprap Failure at Circular Bridge Piers. Journal of Hydraulic $6 \quad$ Engineering 132(4): 354-362.

7 Wu WM and Wang SSY (1999) Movable bed roughness in alluvial rivers. Journal of Hydraulic Engineering 125(12): 1309-1312.

9 Wang X, Sun Y, Lu W and Wang X (2011) Experimental Study of the Effects of Roughness on the Flow Structure in a Gravel-Bed Channel Using Particle Image Velocimetry. Journal of Hydraulic Engineering 16(9): 710-716.

Yanmaz AM and Köse O (2007) Surface characteristics of scouring at bridge elements. Turkish Journal of Engineering and Environmental Sciences 31(2): 127-134.

Zarrati AR, Nazariha M and Mashahir MB (2006) Reduction of local scour in the vicinity of bridge pier groups using collars and riprap. Journal of Hydraulic Engineering 132(2): 154-162. 


\section{Figure Captions:}

2 Figure 1. Side view of the experimental channel.

3 Figure 2. Sketch showing experimental set-up and notation: (a) top view; (b) longitudinal section A-

$4 \quad \mathrm{~A}^{\prime}$; and (c) cross section B-B'.

5 Figure 3. Schematic sketch of adopted debris.

6 Figure 4. Example of arrangement of macro-roughness elements $\left(D_{m}=0.025 \mathrm{~m}\right)$ on the channel bed.

Figure 5. Morphological evolution of the downstream ridge $\left(h / D=5.67, l_{d} / D=3, D_{m} / D=0.83\right)$ : for $\Delta A=6 \%$ (a) 60 minutes and (b) 360 minutes after the test beginning; $\Delta A=18 \%$ (c) 30 minutes and (d) 60 minutes after the test beginning.

Figure 6. Ridge downstream border contour evolution for $\Delta A=6 \%$ and $18 \%, h / D=5.67, l_{d} / D=3$, $D_{m} / D=0.5$

Figure 7. $z_{r, \max } / D$ vs. $T^{*}$ for $h / D=1.40$ and $2.67, \Delta A=6 \%$ and $18 \%, 3 \leq l_{d} / D \leq 5,0 \leq D_{m} / D \leq 0.83$.

Figure 8. $z_{r, \max } / D$ vs $T^{*}$ for $h / D=5.67, \Delta A=6 \%$ and $18 \%, 3 \leq l_{d} / D \leq 5,0 \leq D_{m} / D \leq 0.83$.

Figure 9. Contours for $\Delta A=6 \%$ and debris 5D: (a) test 15, (b) test 7, (c) test 4, (d) test 14, (e) test 6, and (f) test 3 .

Figure 10. Schematic diagram showing the effect of macro-roughness size on temporal scour process:

(a) $D_{m} / D=0.5$, and (b) $D_{m} / D=0.83$.

Figure 11. Histograms representing (a-d) scour volumes and (e-h) scour surface comparison, for different hydraulic conditions and configurations.

Figure 12. Temporal scour evolution: (a) tests 33, 34, 37; (b) tests 26, 27, 30; (c) tests 19, 20, 23; (d) tests $34,37,16,11,8,1,5,2$; (e) tests $27,30,17,12,9,14,6,3$; (f) tests $20,23,18,13,10,15,7,4$; (g) tests 34, 37, 35, 38, 36, 39; (h) tests 27, 30, 28, 31, 29, 32; (i) tests 20, 23, 21, 24, 22, 25; (j) tests 34, 37, 46, 40, 43; 49, 52, 55; (k) tests 27, 30, 47, 41, 44, 50, 53, 56; and (1) tests 20, 23, 48, 42, 45, $51,54,57$ 
1 Figure 13. Comparison between observed and calculated values of scour depths at different instants

2 using (a) Eq. (2) for phase II $\left(0.2 \times 10^{3}<T^{*}<1.0 \times 10^{4}\right)$ and (b) Eq. (3) for phase III $\left(T^{*}>1.0 \times 10^{4}\right)$.

3 


\section{Table Captions:}

2 Table 1 Properties of the tested sediment

3 Table 2 Summary of experimental data

4 


\begin{tabular}{cccccccc}
\hline \multirow{2}{*}{ Sediment } & $\begin{array}{c}d_{16} \\
{[\mathrm{~mm}]}\end{array}$ & $\begin{array}{c}d_{50} \\
{[\mathrm{~mm}]}\end{array}$ & $\begin{array}{c}d_{84} \\
{[\mathrm{~mm}]}\end{array}$ & $\begin{array}{c}\sigma \\
{[-]}\end{array}$ & $\begin{array}{c}\phi \\
{[\mathrm{deg}]}\end{array}$ & $\begin{array}{c}\phi^{\prime} \\
{[\mathrm{deg}]}\end{array}$ & $\begin{array}{c}\Delta \\
{[-]}\end{array}$ \\
\hline Sand & 0.9 & 1.0 & 1.3 & 1.2 & 31 & 36 & 1.44 \\
\hline
\end{tabular}

2

3

Table 1 Properties of the tested sediment

4 


\begin{tabular}{|c|c|c|c|c|c|c|c|c|c|c|c|c|c|}
\hline Test & $\begin{array}{c}D \\
{[\mathrm{~m}]}\end{array}$ & $\begin{array}{c}h / D \\
{[-]}\end{array}$ & $\begin{array}{r}\boldsymbol{F}_{d} \\
{[-]}\end{array}$ & $\begin{array}{c}U / U_{c} \\
{[-]}\end{array}$ & $\begin{array}{c}\text { Debris } \\
{[-]}\end{array}$ & $\begin{array}{c}d_{d} / D \\
{[-]}\end{array}$ & $\begin{array}{l}\Delta A \\
{[\%]}\end{array}$ & $\begin{array}{c}t_{d} / h \\
{[-]}\end{array}$ & $\begin{array}{c}D_{m} / D \\
{[-]}\end{array}$ & $\begin{array}{l}T^{*} \\
{[-]}\end{array}$ & $\begin{array}{c}d_{s} / D \\
{[-]}\end{array}$ & $\begin{array}{c}t \\
{[\mathrm{~min}]}\end{array}$ & $\begin{array}{c}D / d_{50} \\
{[-]}\end{array}$ \\
\hline 1 & 0.03 & 5.67 & 2.72 & 0.96 & 5D & "6.67 & " 6 & 0.22 & $0.00^{* *}$ & 101047704.5 & 2.27 & 3600 & 30.0 \\
\hline 2 & 0.03 & 5.67 & 2.72 & 0.96 & $5 \mathrm{D}$ & 6.67 & 6 & 0.22 & 0.83 & 104770.5 & 2.20 & 360 & 30.0 \\
\hline 3 & 0.03 & 2.67 & 2.93 & 1.00 & $5 \mathrm{D}$ & 6.67 & 6 & 0.22 & 0.83 & 112981.1 & 2.83 & 360 & 30.0 \\
\hline 4 & 0.03 & 1.40 & 2.63 & 1.00 & $5 \mathrm{D}$ & 6.67 & 6 & 0.22 & 0.83 & 101273.2 & 1.60 & 360 & 30.0 \\
\hline 5 & 0.03 & 5.67 & 2.72 & 0.96 & $5 \mathrm{D}$ & 6.67 & 6 & 0.22 & 0.50 & 104770.5 & 2.43 & 360 & 30.0 \\
\hline 6 & 0.03 & 2.67 & 2.93 & 1.00 & $5 \mathrm{D}$ & 6.67 & 6 & 0.22 & 0.50 & 112981.1 & 2.53 & 360 & 30.0 \\
\hline 7 & 0.03 & 1.40 & 2.63 & 1.00 & $5 \mathrm{D}$ & 6.67 & 6 & 0.22 & 0.50 & 101273.2 & 1.43 & 360 & 30.0 \\
\hline 8 & 0.03 & 5.67 & 2.72 & 0.96 & $3 \mathrm{D}$ & 5.67 & 6 & 0.26 & 0.83 & 104770.5 & 2.30 & 360 & 30.0 \\
\hline 9 & 0.03 & 2.67 & 2.93 & 1.00 & $3 \mathrm{D}$ & 5.67 & 6 & 0.26 & 0.83 & 112981.1 & 2.63 & 360 & 30.0 \\
\hline 10 & 0.03 & 1.40 & 2.63 & 1.00 & $3 \mathrm{D}$ & 5.67 & 6 & 0.26 & 0.83 & 101273.2 & 1.80 & 360 & 30.0 \\
\hline 11 & 0.03 & 5.67 & 2.72 & 0.96 & $3 \mathrm{D}$ & 5.67 & 6 & 0.26 & 0.50 & 104770.5 & 2.43 & 360 & 30.0 \\
\hline 12 & 0.03 & 2.67 & 2.93 & 1.00 & $3 \mathrm{D}$ & 5.67 & 6 & 0.26 & 0.50 & 112981.1 & 2.33 & 360 & 30.0 \\
\hline 13 & 0.03 & 1.40 & 2.63 & 1.00 & $3 \mathrm{D}$ & 5.67 & 6 & 0.26 & 0.50 & 101273.2 & 1.40 & 360 & 30.0 \\
\hline 14 & 0.03 & 2.67 & 2.93 & 1.00 & $5 \mathrm{D}$ & 6.67 & 6 & 0.22 & $0.00^{* *}$ & 1129810.6 & 2.43 & 3600 & 30.0 \\
\hline 15 & 0.03 & 1.40 & 2.63 & 1.00 & $5 \mathrm{D}$ & 6.67 & 6 & 0.22 & $0.00^{* *}$ & 1012732.6 & 1.33 & 3600 & 30.0 \\
\hline 16 & 0.03 & 5.67 & 2.72 & 0.96 & $3 \mathrm{D}$ & 5.67 & 6 & 0.26 & $0.00^{* *}$ & 1047704.9 & 2.37 & 3600 & 30.0 \\
\hline 17 & 0.03 & 2.67 & 2.93 & 1.00 & $3 \mathrm{D}$ & 5.67 & 6 & 0.26 & $0.00^{* *}$ & 1129810.6 & 2.57 & 3600 & 30.0 \\
\hline 18 & 0.03 & 1.40 & 2.63 & 1.00 & $3 \mathrm{D}$ & 5.67 & 6 & 0.26 & $0.00^{* *}$ & 1012732.5 & 1.92 & 3600 & 30.0 \\
\hline 19 & 0.03 & 1.40 & 2.63 & 1.00 & $\mathrm{~W} / \mathrm{O}^{*}$ & 0.00 & 0 & 0.00 & $0.00^{* *}$ & 224826.6 & 1.03 & 360 & 30.0 \\
\hline 20 & 0.03 & 1.40 & 2.63 & 1.00 & $\mathrm{~W} / \mathrm{O}^{*}$ & 0.00 & 0 & 0.00 & 0.50 & 224826.6 & 1.07 & 360 & 30.0 \\
\hline 21 & 0.03 & 1.40 & 2.63 & 1.00 & $3 \mathrm{D}$ & 5.67 & 12 & 0.52 & 0.50 & 65356.6 & 1.63 & 360 & 30.0 \\
\hline 22 & 0.03 & 1.40 & 2.63 & 1.00 & $5 \mathrm{D}$ & 6.67 & 12 & 0.43 & 0.50 & 65356.6 & 1.37 & 360 & 30.0 \\
\hline 23 & 0.03 & 1.40 & 2.63 & 1.00 & $\mathrm{~W} / \mathrm{O}^{*}$ & 0.00 & 0 & 0.00 & 0.83 & 224826.6 & 1.03 & 360 & 30.0 \\
\hline 24 & 0.03 & 1.40 & 2.63 & 1.00 & $3 \mathrm{D}$ & 5.67 & 12 & 0.52 & 0.83 & 65356.6 & 1.40 & 360 & 30.0 \\
\hline 25 & 0.03 & 1.40 & 2.63 & 1.00 & $5 \mathrm{D}$ & 6.67 & 12 & 0.43 & 0.83 & 65356.6 & 1.53 & 360 & 30.0 \\
\hline 26 & 0.03 & 2.67 & 2.93 & 1.00 & $\mathrm{~W} / \mathrm{O}^{*}$ & 0.00 & 0 & 0.00 & $0.00^{* *}$ & 250818.0 & 1.80 & 360 & 30.0 \\
\hline 27 & 0.03 & 2.67 & 2.93 & 1.00 & $\mathrm{~W} / \mathrm{O}^{*}$ & 0.00 & 0 & 0.00 & 0.50 & 250818.0 & 1.60 & 360 & 30.0 \\
\hline 28 & 0.03 & 2.67 & 2.93 & 1.00 & $3 \mathrm{D}$ & 5.67 & 12 & 0.52 & 0.50 & 72912.2 & 3.03 & 360 & 30.0 \\
\hline 29 & 0.03 & 2.67 & 2.93 & 1.00 & $5 \mathrm{D}$ & 6.67 & 12 & 0.43 & 0.50 & 72912.2 & 2.63 & 360 & 30.0 \\
\hline 30 & 0.03 & 2.67 & 2.93 & 1.00 & $\mathrm{~W} / \mathrm{O}^{*}$ & 0.00 & 0 & 0.00 & 0.83 & 250818.0 & 1.80 & 360 & 30.0 \\
\hline 31 & 0.03 & 2.67 & 2.93 & 1.00 & $3 \mathrm{D}$ & 5.67 & 12 & 0.52 & 0.83 & 72912.2 & 3.00 & 360 & 30.0 \\
\hline 32 & 0.03 & 2.67 & 2.93 & 1.00 & $5 \mathrm{D}$ & 6.67 & 12 & 0.43 & 0.83 & 72912.2 & 2.67 & 360 & 30.0 \\
\hline 33 & 0.03 & 5.67 & 2.72 & 0.96 & $\mathrm{~W} / \mathrm{O}^{*}$ & 0.00 & 0 & 0.00 & $0.00^{* *}$ & 232590.5 & 1.47 & 360 & 30.0 \\
\hline 34 & 0.03 & 5.67 & 2.72 & 0.96 & $\mathrm{~W} / \mathrm{O}^{*}$ & 0.00 & 0 & 0.00 & 0.50 & 232590.5 & 1.23 & 360 & 30.0 \\
\hline 35 & 0.03 & 5.67 & 2.72 & 0.96 & $3 \mathrm{D}$ & 5.67 & 12 & 0.52 & 0.50 & 67613.5 & 3.17 & 360 & 30.0 \\
\hline 36 & 0.03 & 5.67 & 2.72 & 0.96 & $5 \mathrm{D}$ & 6.67 & 12 & 0.43 & 0.50 & 67613.5 & 2.53 & 360 & 30.0 \\
\hline 37 & 0.03 & 5.67 & 2.72 & 0.96 & $\mathrm{~W} / \mathrm{O}^{*}$ & 0.00 & 0 & 0.00 & 0.83 & 232590.5 & 1.03 & 360 & 30.0 \\
\hline 38 & 0.03 & 5.67 & 2.72 & 0.96 & $3 \mathrm{D}$ & 5.67 & 12 & 0.52 & 0.83 & 67613.5 & 2.90 & 360 & 30.0 \\
\hline 39 & 0.03 & 5.67 & 2.72 & 0.96 & $5 \mathrm{D}$ & 6.67 & 12 & 0.43 & 0.83 & 67613.5 & 2.50 & 360 & 30.0 \\
\hline 40 & 0.03 & 5.67 & 2.72 & 0.96 & $3 \mathrm{D}$ & 5.67 & 18 & 0.78 & 0.50 & 49912.1 & 3.23 & 360 & 30.0 \\
\hline 41 & 0.03 & 2.67 & 2.93 & 1.00 & $3 \mathrm{D}$ & 5.67 & 18 & 0.78 & 0.50 & 53823.6 & 3.40 & 360 & 30.0 \\
\hline 42 & 0.03 & 1.40 & 2.63 & 1.00 & $3 \mathrm{D}$ & 5.67 & 18 & 0.78 & 0.50 & 48246.1 & 1.97 & 360 & 30.0 \\
\hline 43 & 0.03 & 5.67 & 2.72 & 0.96 & $3 \mathrm{D}$ & 5.67 & 18 & 0.78 & 0.83 & 49912.1 & 3.33 & 360 & 30.0 \\
\hline 44 & 0.03 & 2.67 & 2.93 & 1.00 & $3 \mathrm{D}$ & 5.67 & 18 & 0.78 & 0.83 & 53823.6 & 3.40 & 360 & 30.0 \\
\hline 45 & 0.03 & 1.40 & 2.63 & 1.00 & $3 \mathrm{D}$ & 5.67 & 18 & 0.78 & 0.83 & 48246.1 & 1.63 & 360 & 30.0 \\
\hline 46 & 0.03 & 5.67 & 2.72 & 0.96 & $3 \mathrm{D}$ & 5.67 & 18 & 0.78 & $0.00^{* *}$ & 49912.1 & 3.47 & 360 & 30.0 \\
\hline 47 & 0.03 & 2.67 & 2.93 & 1.00 & $3 \mathrm{D}$ & 5.67 & 18 & 0.78 & $0.00^{* *}$ & 53823.6 & 3.67 & 360 & 30.0 \\
\hline 48 & 0.03 & 1.40 & 2.63 & 1.00 & $3 \mathrm{D}$ & 5.67 & 18 & 0.78 & $0.00^{* *}$ & 48246.1 & 1.87 & 360 & 30.0 \\
\hline 49 & 0.03 & 5.67 & 2.72 & 0.96 & $5 \mathrm{D}$ & 6.67 & 18 & 0.65 & $0.00^{* *}$ & 49912.1 & 3.53 & 360 & 30.0 \\
\hline 50 & 0.03 & 2.67 & 2.93 & 1.00 & $5 \mathrm{D}$ & 6.67 & 18 & 0.65 & $0.00^{* *}$ & 53823.6 & 3.53 & 360 & 30.0 \\
\hline 51 & 0.03 & 1.40 & 2.63 & 1.00 & $5 \mathrm{D}$ & 6.67 & 18 & 0.65 & $0.00^{* *}$ & 48246.1 & 2.07 & 360 & 30.0 \\
\hline 52 & 0.03 & 5.67 & 2.72 & 0.96 & $5 \mathrm{D}$ & 6.67 & 18 & 0.65 & 0.50 & 49912.1 & 3.60 & 360 & 30.0 \\
\hline 53 & 0.03 & 2.67 & 2.93 & 1.00 & $5 \mathrm{D}$ & 6.67 & 18 & 0.65 & 0.50 & 53823.6 & 3.10 & 360 & 30.0 \\
\hline 54 & 0.03 & 1.40 & 2.63 & 1.00 & $5 \mathrm{D}$ & 6.67 & 18 & 0.65 & 0.50 & 48246.1 & 1.97 & 360 & 30.0 \\
\hline 55 & 0.03 & 5.67 & 2.72 & 0.96 & $5 \mathrm{D}$ & 6.67 & 18 & 0.65 & 0.83 & 49912.1 & 3.17 & 360 & 30.0 \\
\hline 56 & 0.03 & 2.67 & 2.93 & 1.00 & $5 \mathrm{D}$ & 6.67 & 18 & 0.65 & 0.83 & 53823.6 & 3.33 & 360 & 30.0 \\
\hline 57 & 0.03 & 1.40 & 2.63 & 1.00 & $5 \mathrm{D}$ & 6.67 & 18 & 0.65 & 0.83 & 48246.1 & 1.93 & 360 & 30.0 \\
\hline
\end{tabular}




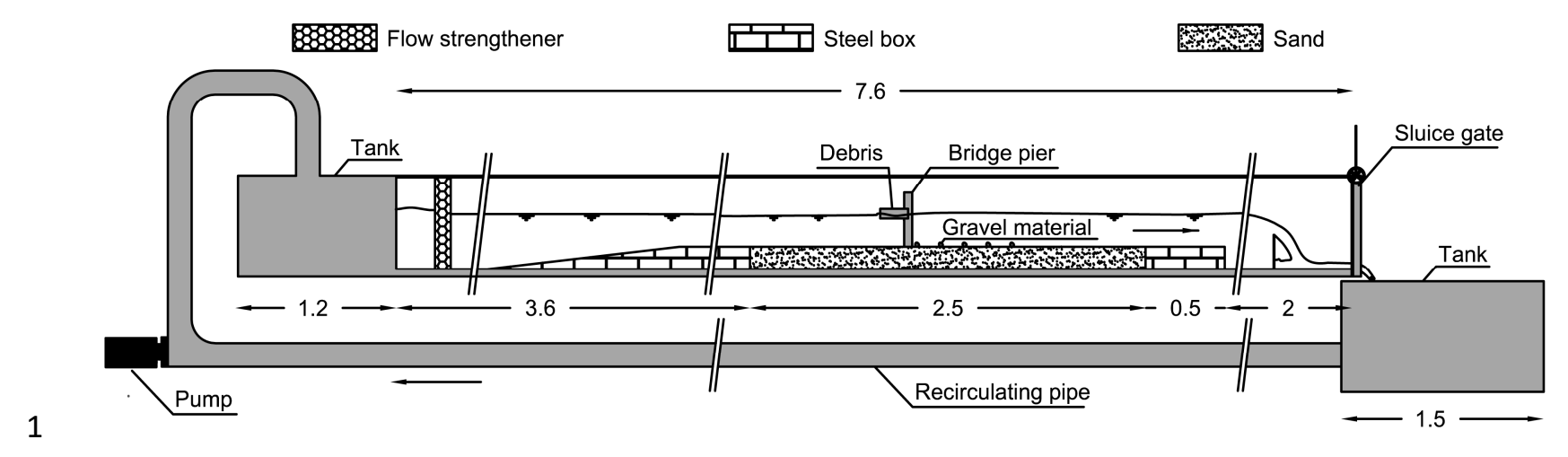

2 Figure 1. Side view of the experimental channel.

3 
(a)

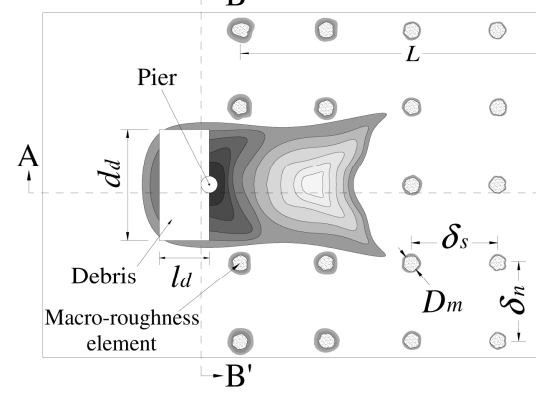

(b)

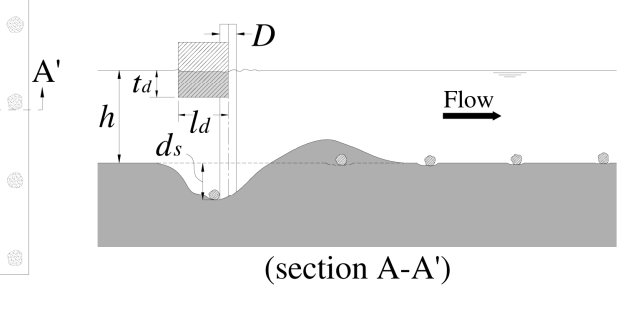

(c)

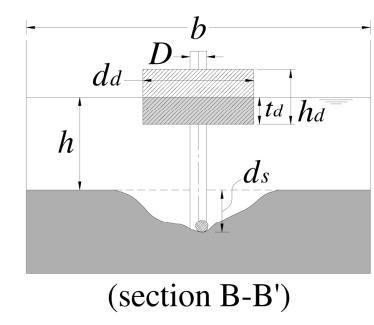

2 Figure 2. Sketch showing experimental set-up and notation: (a) top view; (b) longitudinal section A$3 \quad \mathrm{~A}^{\prime}$; and (c) cross section B-B'. 


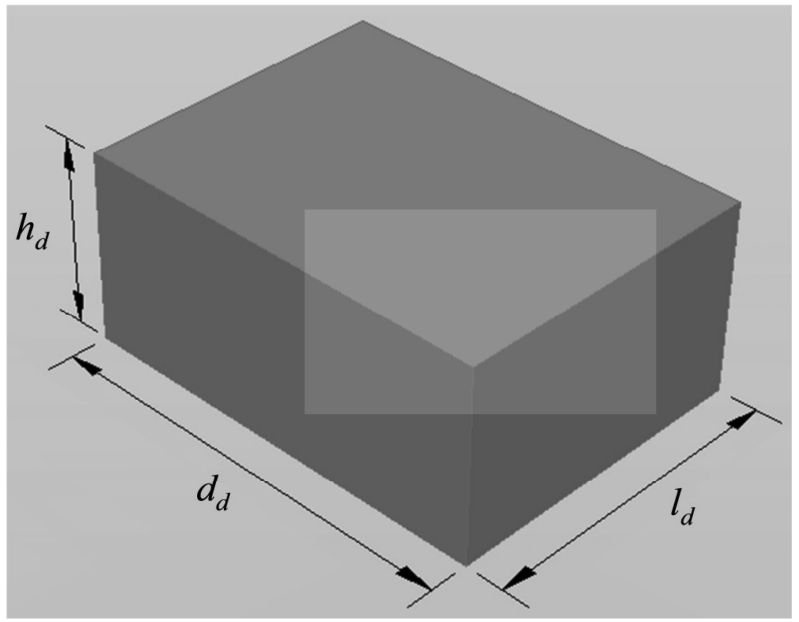

2 Figure 3. Schematic sketch of adopted debris.

3 


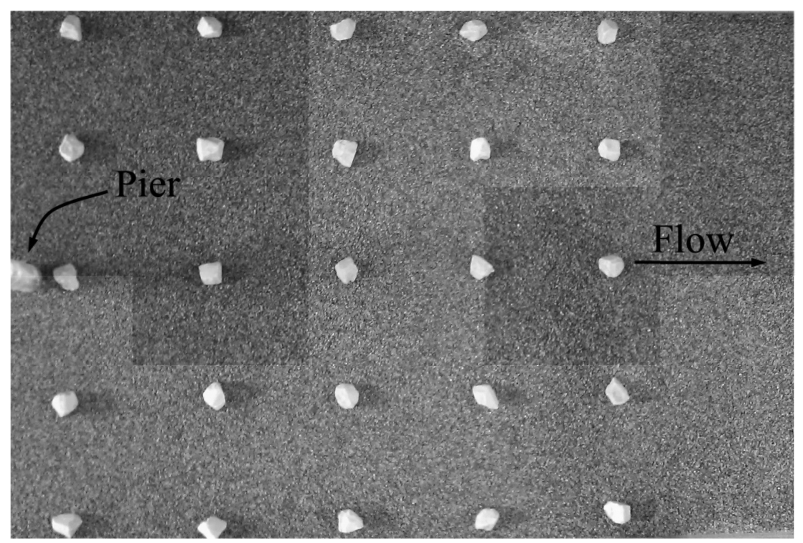

2 Figure 4. Example of arrangement of macro-roughness elements $\left(D_{m}=0.025 \mathrm{~m}\right)$ on the channel bed.

3 

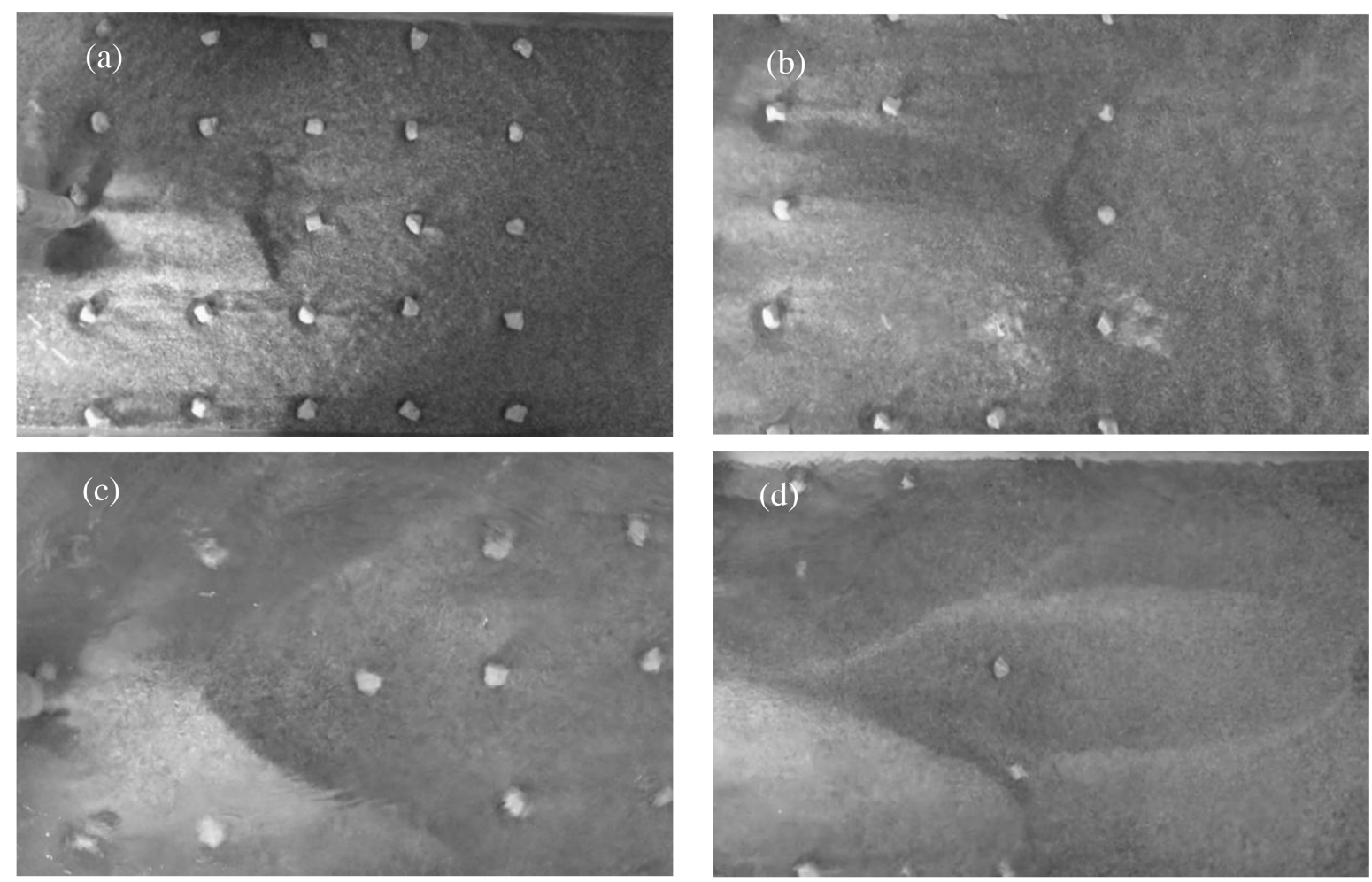

1

2 Figure 5. Morphological evolution of the downstream ridge $\left(h / D=5.67, l_{d} / D=3, D_{m} / D=0.83\right)$ : for

$3 \Delta A=6 \%$ (a) 60 minutes and (b) 360 minutes after the test beginning; $\Delta A=18 \%$ (c) 30 minutes and

4

(d) 60 minutes after the test beginning.

5 


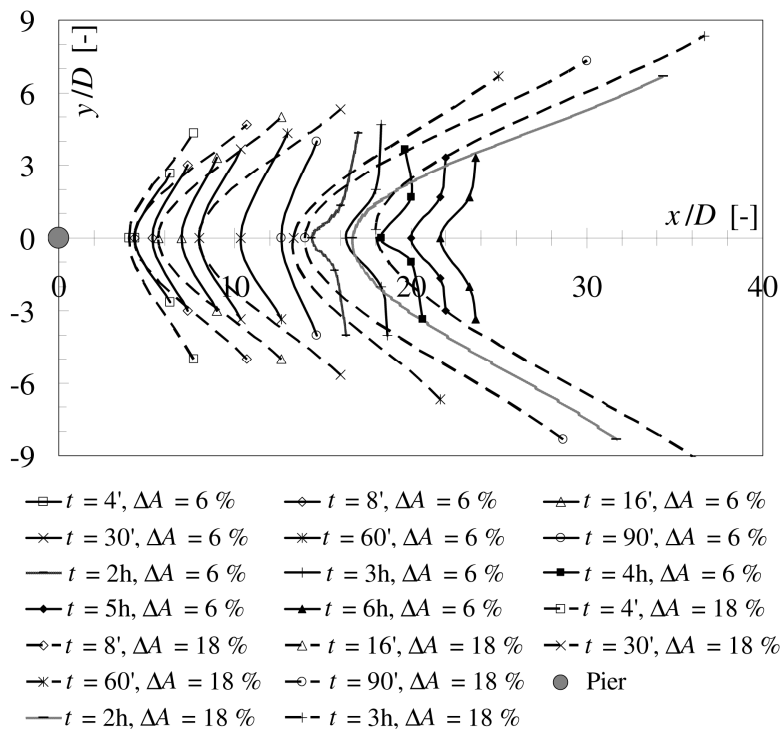

2 Figure 6. Ridge downstream border contour evolution for $\Delta A=6 \%$ and $18 \%, h / D=5.67, l_{d} / D=3$, $3 D_{m} / D=0.5$. 


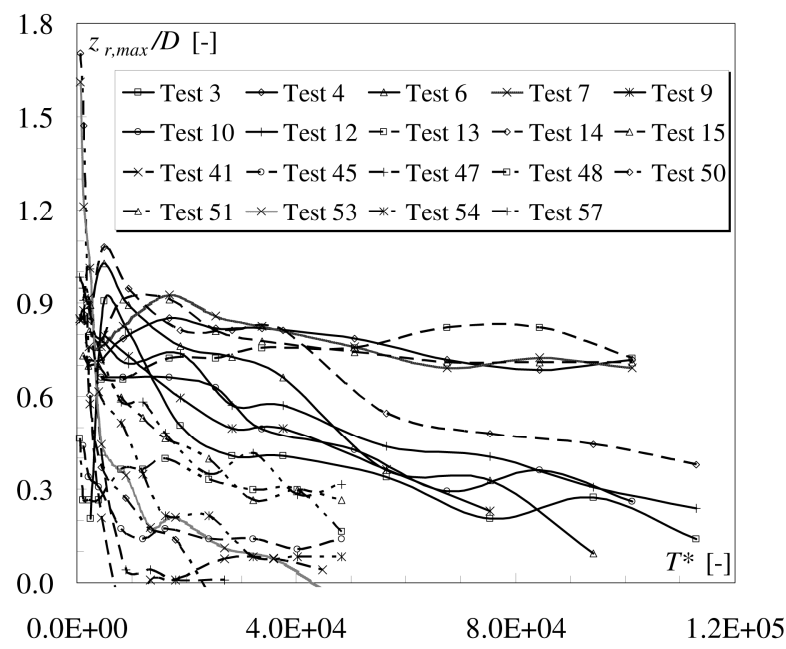

2 Figure 7. $z_{r, \max } / D$ vs. $T^{*}$ for $h / D=1.40$ and $2.67, \Delta A=6 \%$ and $18 \%, 3 \leq l_{d} / D \leq 5,0 \leq D_{m} / D \leq 0.83$. 


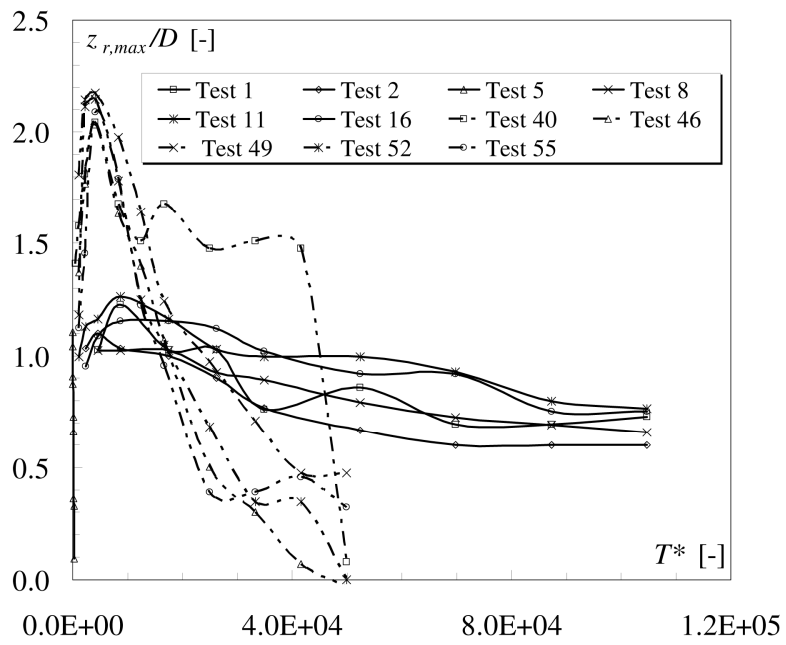

2 Figure 8. $z_{r, \max } / D$ vs $T^{*}$ for $h / D=5.67, \Delta A=6 \%$ and $18 \%, 3 \leq l_{d} / D \leq 5,0 \leq D_{m} / D \leq 0.83$.

3 

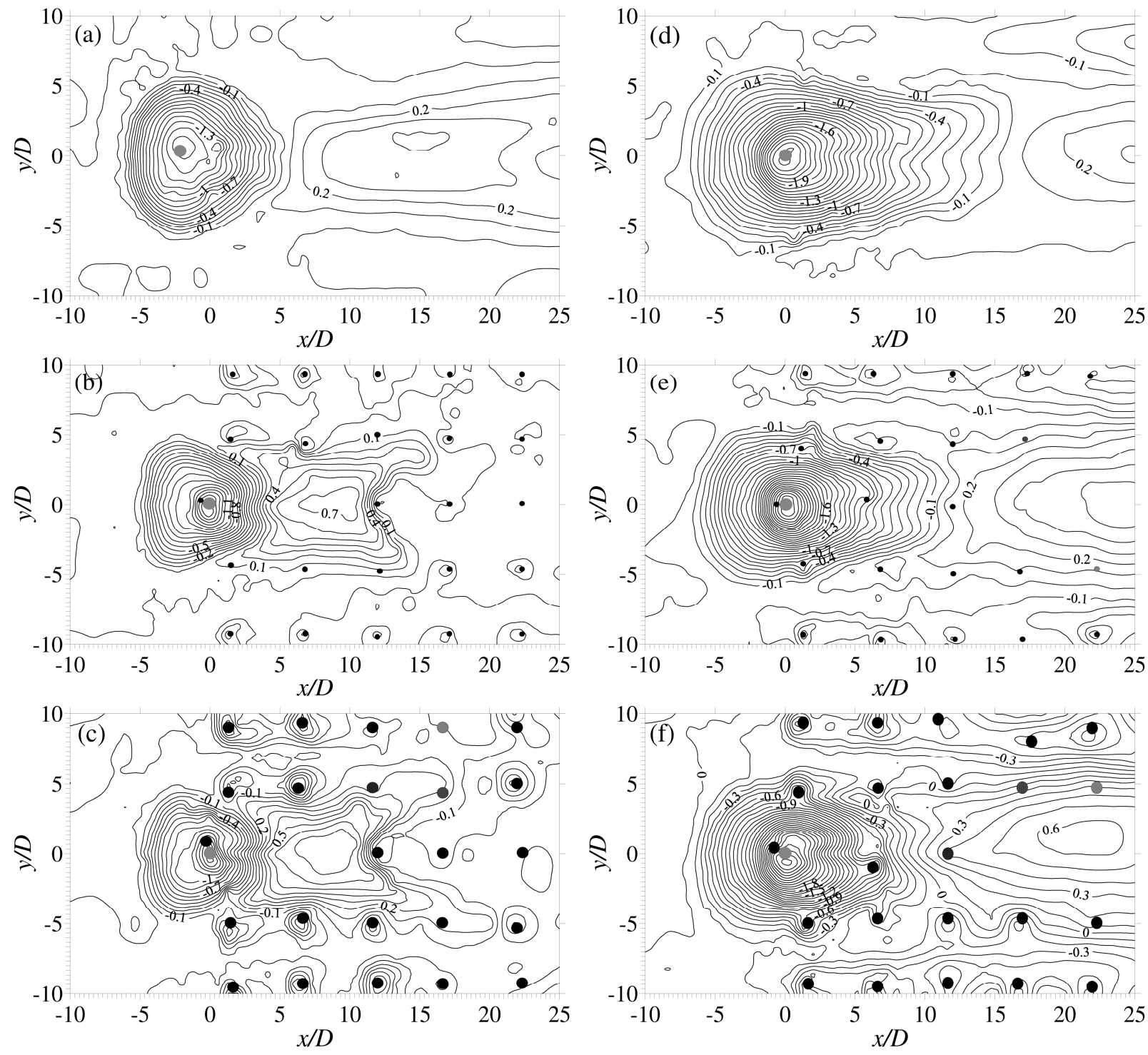

Figure 9. Contours for $\Delta A=6 \%$ and debris 5D: (a) test 15, (b) test 7, (c) test 4, (d) test 14, (e) test 6, 3 and (f) test 3. 

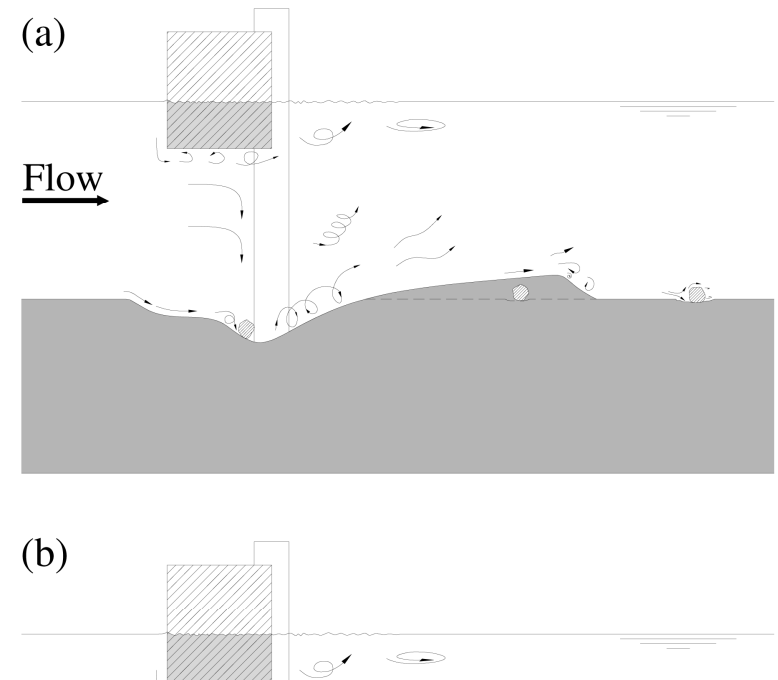

\section{$\stackrel{\text { Flow }}{\longrightarrow}$}

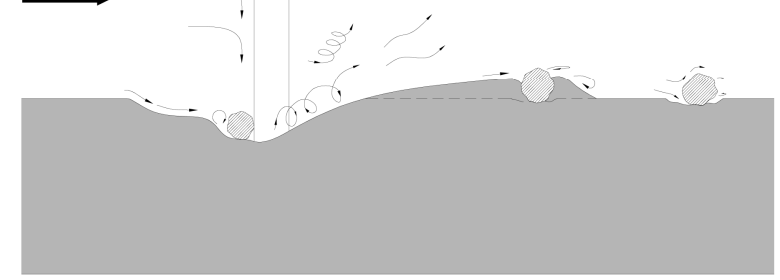

2 Figure 10. Schematic diagram showing the effect of macro-roughness size on temporal scour process:

3

(a) $D_{m} / D=0.5$, and (b) $D_{m} / D=0.83$.

4 

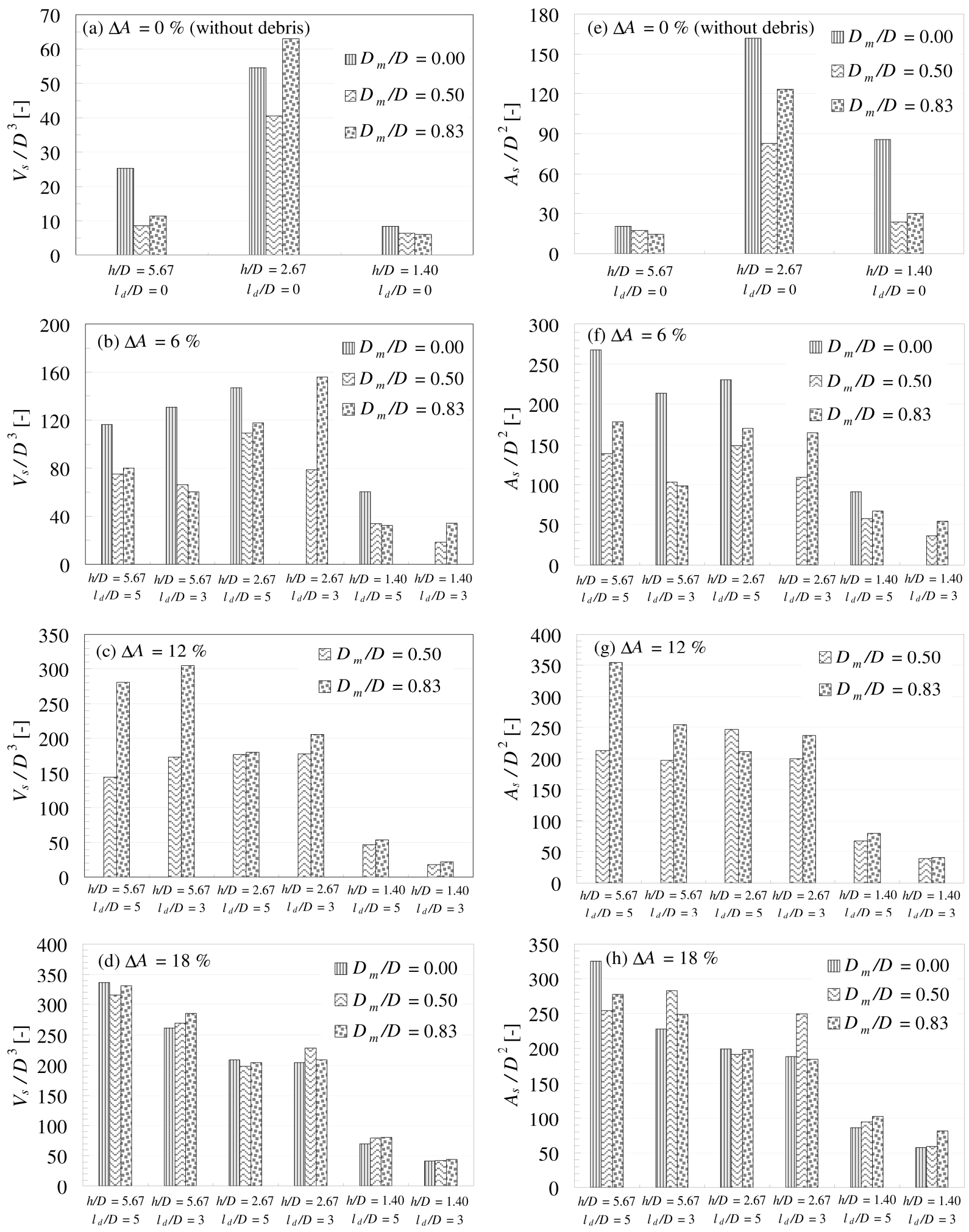

2 Figure 11. Histograms representing (a-d) scour volumes and (e-h) scour surface comparison, for 3 different hydraulic conditions and configurations. 

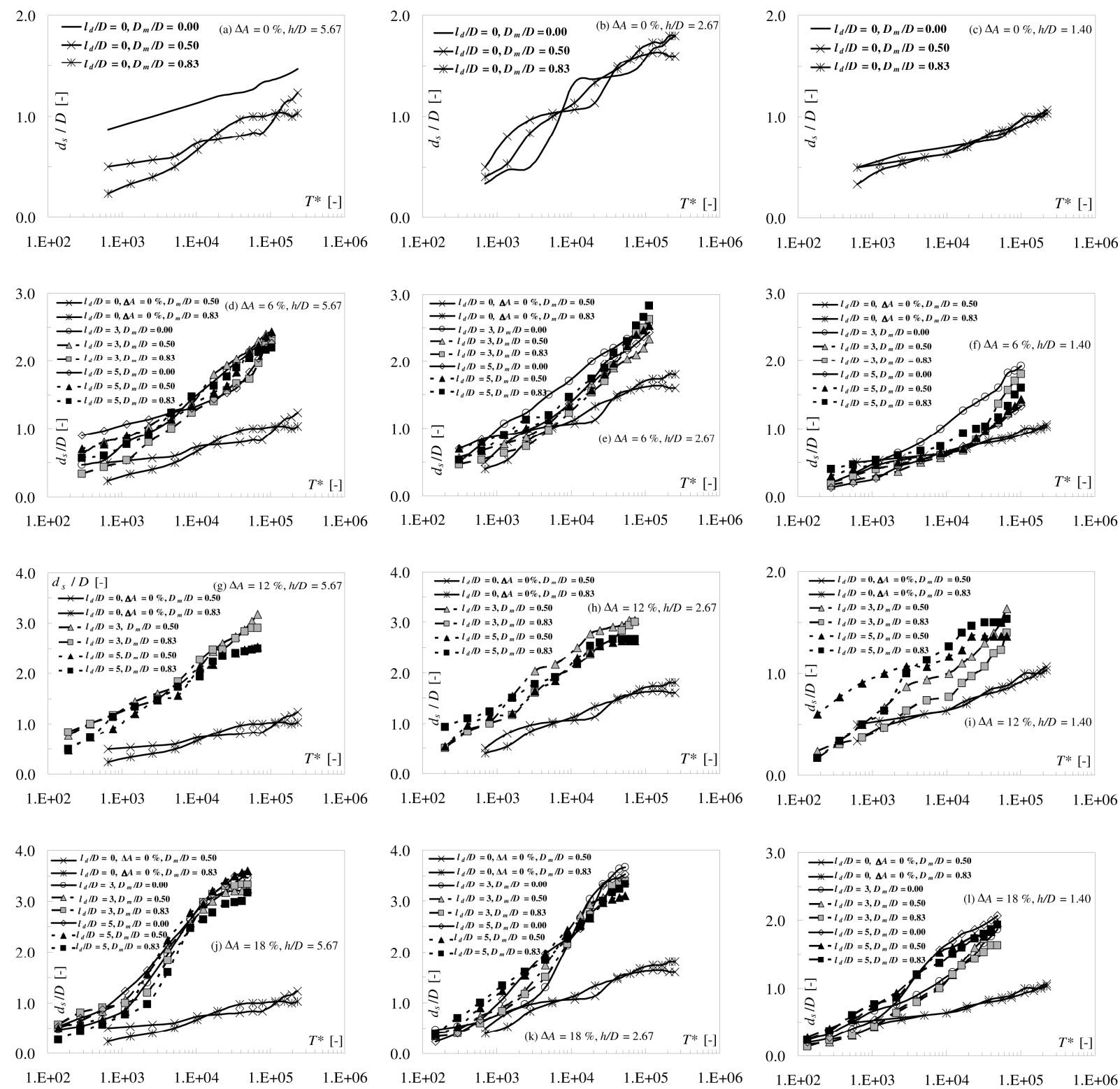

$1 . \mathrm{E}+02 \quad 1 . \mathrm{E}+03 \quad 1 . \mathrm{E}+04 \quad 1 . \mathrm{E}+05 \quad 1 . \mathrm{E}+06$

$1 . \mathrm{E}+02 \quad 1 . \mathrm{E}+03 \quad 1 . \mathrm{E}+04 \quad 1 . \mathrm{E}+05 \quad 1 . \mathrm{E}+06$

Figure 12. Temporal scour evolution: (a) tests 33, 34, 37; (b) tests 26, 27, 30; (c) tests 19, 20, 23; (d)

3 tests $34,37,16,11,8,1,5,2$; (e) tests $27,30,17,12,9,14,6,3$; (f) tests $20,23,18,13,10,15,7,4$;

4 (g) tests 34, 37, 35, 38, 36, 39; (h) tests 27, 30, 28, 31, 29, 32; (i) tests 20, 23, 21, 24, 22, 25; (j) tests

$534,37,46,40,43 ; 49,52,55$; (k) tests $27,30,47,41,44,50,53,56$; and (1) tests 20, 23, 48, 42, 45,

$6 \quad 51,54,57$. 

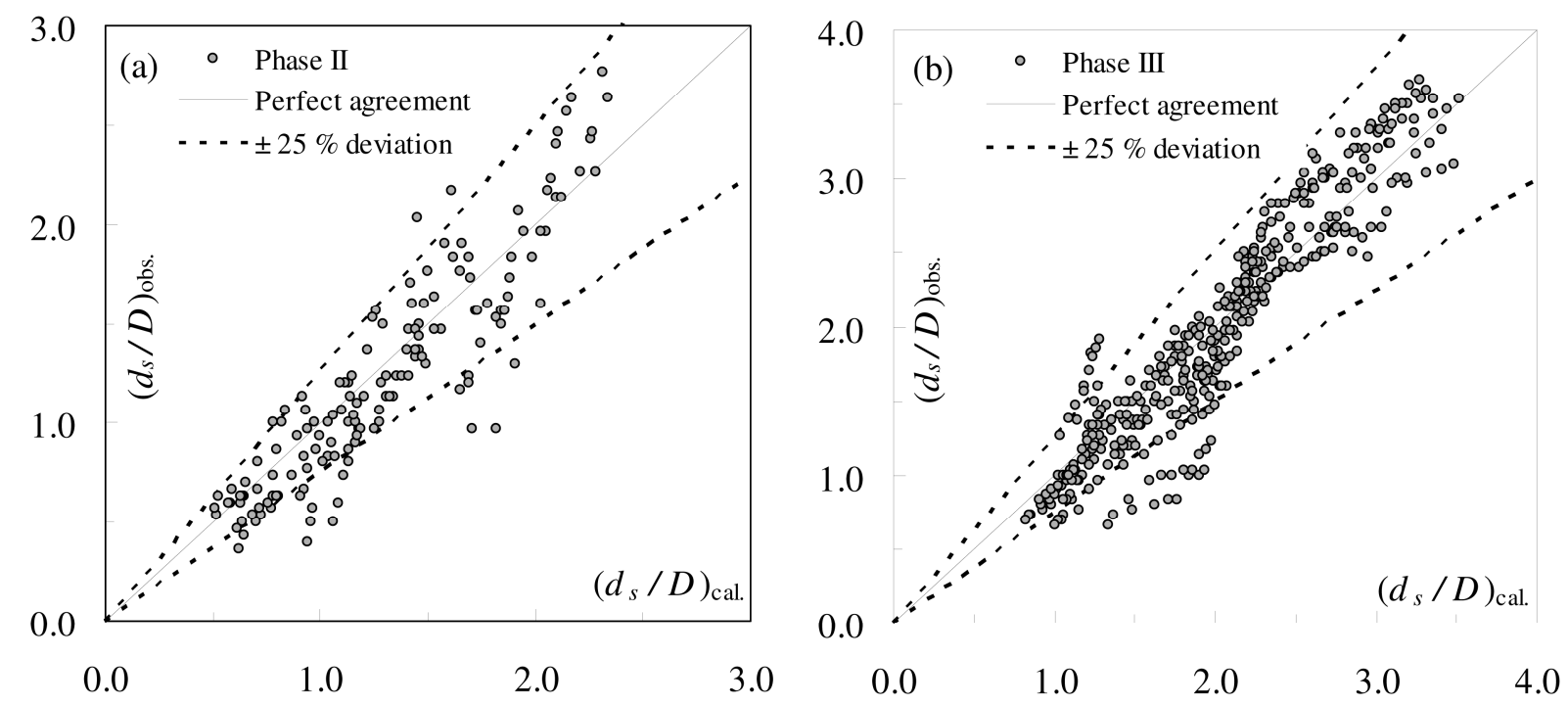

1

Figure 13. Comparison between observed and calculated values of scour depths at different instants using (a) Eq. (2) for phase II $\left(0.2 \times 10^{3}<T^{*}<1.0 \times 10^{4}\right)$ and (b) Eq. (3) for phase III $\left(T^{*}>1.0 \times 10^{4}\right)$. 